\title{
Adsorptive Removal of Fluoride from Aqueous Solution by Biogenic Iron Permeated Activated Carbon Derived from Sweet Lime Waste
}

\author{
Mohd. Ibrahim, ${ }^{1}$ Adil Siddique, ${ }^{1}$ Lata Verma, ${ }^{1}$ Jiwan Singh ${ }^{1, *}$ \\ and Janardhan Reddy Koduru ${ }^{2, *}$ \\ ${ }^{1}$ Department of Environmental Science, Babasaheb Bhimrao Ambedkar University, Lucknow-226025, India \\ ${ }^{2}$ Department of Environmental Engineering, Kwangwoon University, Seoul 139-701, Republic of Korea \\ *Corresponding author: E-mail: jiwansingh95@gmail.com \\ reddyjchem@gmail.com
}

Received: 09-14-2018

\begin{abstract}
In this study, biogenic activated carbon were successfully synthesized from Citrus limetta pulp residue, and applied to remove fluoride from an aqueous solution. For the synthesis activated carbon of biosorbents, raw materials were heated in muffle furnace at two different temperatures i.e. $\left(250^{\circ} \mathrm{C}\right.$ and $\left.500{ }^{\circ} \mathrm{C}\right)$ and were noted as ACP-250 and ACP-500. The prepared biosorbents were characterized through scanning electron microscopy (SEM), Fourier transform infrared (FTIR), and X-ray diffraction (XRD). Batch adsorption studies were performed with varying temperature, dosage, $\mathrm{pH}$, and various initial concentrations. Adsorption isotherms and the reaction kinetics were also analyzed in order to understand the adsorption mechanism. The results of this study shows that the maximum removal achieved was approximately (86 and 82) \% of ACP-500 and ACP-250, respectively. The isotherm results show that the Langmuir isotherm model fitted better, with monolayer adsorption capacity of $12.6 \mathrm{mg} / \mathrm{g}$ of fluoride. However, for kinetic study, the pseudo-second-order kinetics fitted well. The synthesized materials at different temperature were highly effective for the removal of fluoride from water, with reusability of three to four times.
\end{abstract}

Keywords: Sweet lime waste; adsorption; fluoride; isotherm; thermodynamic; cost analysis.

\section{Introduction}

The presence of fluoride in drinking water offerings a severe complication worldwide ${ }^{1}$. In India, more than $95 \%$ of rural and (30-40) \% of the urban population are dependent on groundwater. ${ }^{2}$ The higher amount of fluoride in groundwater is dangerous for drinking purposes. Normally, fluoride is released in groundwater through the slow leaching of fluorine-containing rock, ${ }^{3}$ and of several minerals viz., topaz, biotite, fluorite, and their corresponding host rock, such as basalt, syenite, granite, etc. ${ }^{4}$ Moreover, while the natural geological source contributes fluoride to groundwater, several industries also contribute to fluoride contamination. ${ }^{5}$ According to Shen et al. ${ }^{6}$ some industries generate fluoride in the environment, and discharge higher fluoride concentration than natural geological dissolution, ranging $(10-1,000) \mathrm{mg} / \mathrm{L}{ }^{7}$ More than 200 million people worldwide are affected by higher fluoride concentration that exceeds the WHO guideline of $1.5 \mathrm{mg} / \mathrm{L} .{ }^{8}$ Contamination of fluoride occurs in different parts of India, including Andhra Pradesh, Assam, Gujarat, Haryana, Rajasthan, and Uttar Pradesh. ${ }^{9}$ The amount of fluoride in groundwater in some parts of India is above $30 \mathrm{mg} / \mathrm{L} .{ }^{10}$ The impact of fluoride in drinking water depends on the concentration and duration of continuous uptake, and can be useful or harmful to humankind. Even a small concentration of fluoride in water has a significant effect on dental caries, mainly among children. ${ }^{11}$ An excessive amount of fluoride causes various diseases, such as osteoporosis, arthritis, brittle bones, cancer, infertility, brain damage, Alzheimer syndrome, and thyroid disorder. ${ }^{12}$ Among these diseases, fluorosis is one of the most common diseases in human who are consuming fluoride regularly, also causing mottling of the teeth, and embrittlement of the bones of human. ${ }^{13}$ Hence, there is necessity to treat of water contaminated with fluoride before drink or release to environment. 
Many technologies, such as chemical precipitation, coagulation, ion exchange, electrocoagulation, nanofiltration, catalytic ozonation, and electrochemical oxidation $^{14-18}$ and Donnan dialysis ${ }^{19}$ have been used for the fluoridation of water. However those methods have limitations in terms of high operational and maintenance cost, and generation of waste. The adsorptive removal of fluoride has been considered one of the most facile, cost-effective, and eco-friendly techniques among the various defluoridation technologies. ${ }^{14-20}$ Several adsorbents, including various conventional and non-convention sorbents/biosorbents, such as red mud, bone char, rare earth oxides, zeolite, citrus lemon leaves, rice husk ash, peepal leaf, musambi peel, banana peel, and laterite soils, have been reported for the defluoridation of water. ${ }^{21}$ However, most biosorbents have low fluoride removal abilities to treat fluoride-contaminated groundwater. Therefore, the development of better bioadsorbents with superior adsorption capacities for fluoride is still needed. Given the higher cost of production, presented agriculture solid waste is being intensively studied for the production of low-cost activated carbons. Waste materials that are converted into activated carbon improve economic value, reduce the cost of waste disposal, and potentially offer a cheap alternative to the current viable sample. ${ }^{22}$

However, functionalizing iron-oxide nanoparticles with parent biosorbent, improving adsorption capacity, selectivity and stability levels of tested materials. ${ }^{23}$ So, these functionalized activated carbons with iron oxide are great interest for removing pollutants from water. Moreover, the modification of biogenic activated carbon with iron oxide that can enhances its adsorption ability and selectivity of parent material. ${ }^{24}$
In the present study, Citrus limetta pulp was used for the synthesis of biogenic activated carbon permeated with iron. It is valuable waste material that is thrown away from the juice industry, and engenders land space occupation and pollution with phenolic compounds, due to the dumping of wastes. Natural biomaterial waste citrus limetta pulp was used as a template, and $\mathrm{FeCl}_{3} \cdot 6 \mathrm{H}_{2} \mathrm{O}$ was used for the iron precursor source to develop magnetic properties in both the adsorbents for the removal of fluoride from an aqueous solution. Two adsorbents were prepared at two different temperatures of (250 and 500$)^{\circ} \mathrm{C}$ for the potential application for fluoride removal.

\section{Materials and Methods}

\section{1. Chemicals}

For the purpose of the research work, analytical grade chemicals were used. These chemicals were anhydrous sodium fluoride $(\mathrm{NaF})$, iron chloride hexahydrate $\left(\mathrm{FeCl}_{3}, 6 \mathrm{H}_{2} \mathrm{O}\right)$, sodium hydroxide $(\mathrm{NaOH})$, hydrochloric acid ( $\mathrm{HCl}$ ), and Ionic Strength Adjustment (ISA) Solution, purchased from Fisher Scientific (a part of Thermos Fisher Scientific).

\section{2. Preparation of Pulp powder}

Citrus limetta (sweet lime) pulp waste was collected from a local juice seller nearby the area of BBAU, Lucknow, India. Plenty of water was required for the washing of raw material so firstly the tap water was used for washing of collected pulp material to eliminate the dust particles and other adherence from the surface of collected material, af-

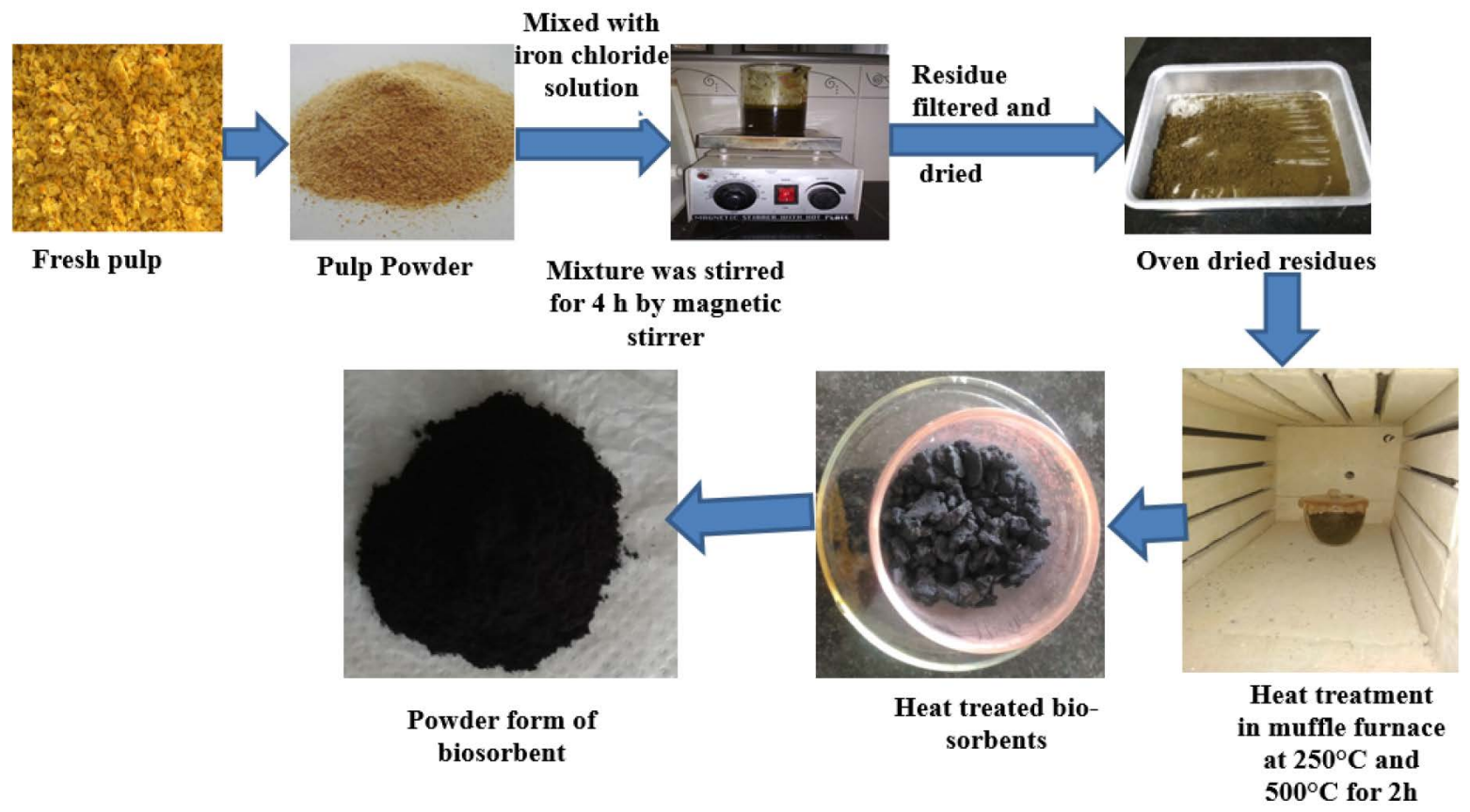

Figure 1. A flowchart for the synthesis of biogenic iron permeated activated carbon (ACP- 250 and ACP-500). 
ter that the material was washed with distilled water atleast three times. The study area is not affected by fluoride. Pulp waste was chopped in small pieces, and then air-dried. The dried pulp was crushed and ground with the help of grinder, and finally, powder forms were obtained by sieving with $250 \mu \mathrm{m}$ sieve. The sieved powder was used for the preparation of activated carbon (bio-sorbents).

\subsection{Synthesis of Biogenic Iron Permeated Activated Carbon}

Bioadsorbents were prepared according to the method given by Lunge. ${ }^{25}$ The details of synthesis are that $15 \mathrm{~g}$ of Iron chloride hexahydrate $\left(\mathrm{FeCl}_{3} \cdot 6 \mathrm{H}_{2} \mathrm{O}\right)$ was dissolved in $150 \mathrm{~mL}$ of distilled water, and $30 \mathrm{~g}$ of fine pulp powder was added and stirred for $4 \mathrm{~h}$, and kept overnight, then, the solid materials were separated by vacuum pump filtration, followed by oven drying at $105^{\circ} \mathrm{C}$ for $4 \mathrm{~h}$. The iron-treated material was heated in a muffle furnace (Model No.11C 106B; ICOAN Instruments Company, India) at two different temperatures i.e. ( 250 and 500$)^{\circ} \mathrm{C}$ for $2 \mathrm{~h}$.

Iron chloride hexahydrate was used for the preparation of ACP to develop magnetic properties and acidic nature to the ACP. Moreover, the addition of $\mathrm{FeCl}_{3}$ can be improve positive surface which is favorable for adsorption negative charge fluoride. The heated material was washed with double distilled water, and then dried. A black color final product was obtained named as activated carbon of pulp, denoted as ACP-250 and ACP-500. These materials were ground and made uniform using mortar and pestle, and applied for the fluoride removal. Fig. 1 shows the different steps in the synthesis of bioadsorbents.

\section{4. Preparation of Standard Solution of Fluoride and its Determination}

For the purpose of batch experiment, different concentrations of fluoride solution were prepared by diluting the stock solution of $1,000 \mathrm{mg} / \mathrm{L}$ concentration of $\mathrm{F}^{-}(\mathrm{a}$ stock solution prepared by $\mathrm{NaF}$ salt). The concentration of fluoride and $\mathrm{pH}$ of the solution was determined by digital Ion-pH meter (EUTECH Handheld Meter Kit; Thermo Scientific).

\section{5. Spectroscopy and Microscopy Identification of Adsorbents}

The XRD configuration of the biosorbent was attained by X-ray Diffractometer (PW 30 40/60, PANalytical, Netherlands), which was used to analyze the phase and structure of both biosorbents. Surface morphology, structure, and elemental composition of the biosorbents were obtained with SEM equipped with EDX (JSM 6490LV, JEOL, Japan). Various functional groups analysis of the adsorbents were analyzed by using FTIR Spectrophotometry (NICOLETTM 6700, Thermo Scientific, USA) with
$\mathrm{KBr}$ at a ratio of 1:200, and the mixture was pressed, as reference material and spectra were detailed in the region of (400 to 4,000) $\mathrm{cm}^{-1}$. The synthesized bioadsorbents were analyzed for surface charge i.e. zero point charge (pHzpc), by the method reported by Sharma. ${ }^{10}$

\section{6. Procedure for Adsorptive Removal of Fluoride}

A $50 \mathrm{~mL}$ of fluoride solution $(10 \mathrm{mg} / \mathrm{L})$ was mixed with $1 \mathrm{~g} / \mathrm{L}$ dose of biogenic activated carbon material, and kept in horizontal water bath shaker (LI-WBIS-20; Labard Instruchem. Pvt. Ltd) at $25{ }^{\circ} \mathrm{C}$ for $5 \mathrm{~h}$ for shaking at $100 \mathrm{rpm}$. Samples were collected at different time intervals. The optimum conditions for maximum removal of fluoride using biadsorbents have been estimated by observing the effect of contact time of (30-300) min, initial $\mathrm{pH}$ of (4-10), adsorbent dose of (0.5-3.0) g/L, temperature of $\left(25-55^{\circ} \mathrm{C}\right)$, and initial fluoride concentrations of (5-30) $\mathrm{mg} / \mathrm{L}$ at $100 \mathrm{rpm}$; then the flasks were taken at different time intervals from the water bath shaker, followed by filtration through Whatman 42 filter paper. The filtrate was used for the determination of the remaining fluoride ions using ion selective electrode contain digital Ion-pH meter. The batch study was carried out in duplicate, and average values were calculated, and taken as the final value.

The fluoride removal efficiency using biosorbents (ACP-250 and ACP-500) during adsorption was calculated as follows:

Removal efficiency $(\%)=\left(\left(\mathrm{C}_{0}-\mathrm{C}_{\mathrm{i}}\right) / \mathrm{C}_{0}\right) \times 100$

The amount of adsorbed $\mathrm{F}^{-}$per unit mass of adsorbent was obtained using the formula:

$$
\mathrm{q}_{\mathrm{e}}=\left(\mathrm{C}_{0}-\mathrm{C}_{\mathrm{e}}\right) \mathrm{V} / \mathrm{W}
$$

Where, $\mathrm{q}_{\mathrm{e}}$ is the adsorption capacity of $\mathrm{F}^{-}(\mathrm{mg} / \mathrm{g})$; $\mathrm{C}_{\mathrm{o}}$ is the initial F- concentration $(\mathrm{mg} / \mathrm{L}) ; \mathrm{C}_{\mathrm{e}}$ is the $\mathrm{F}^{-}$concentration at equilibrium $(\mathrm{mg} / \mathrm{L})$; $\mathrm{W}$ is the adsorbent mass $(\mathrm{g})$, and $\mathrm{V}$ is the volume of $\mathrm{F}^{-}$solution $(\mathrm{L})$.

\section{Results and Discussion}

\section{1. Characterization of Biosorbent}

\section{1. 1. Zero Point Charge $\left(\mathrm{pH}_{\mathrm{zpc}}\right)$}

The $\mathrm{pH}_{\mathrm{zpc}}$ of an adsorbing material is a significant parameter that regulates the $\mathrm{pH}$ at which the adsorbent surface has net electrical charge neutral. In the case $\mathrm{pH}$ of solution $<\mathrm{pHzpc}$, the adsorbent surface charge is positive to attract negative ions; however, when $\mathrm{pH}$ of solution $>$ $\mathrm{pHzpc}$, then the surface charge of adsorbent is negative to attract positive ions. ${ }^{26}$ The pHzpc of the prepared materials, ACP-250 and ACP-500 have been found to be 2.66 
and 3.06, respectively. From the results, both biosorbents may have more acidic functional groups such as carboxylic, phenolic groups etc., on their surfaces. It is fact that the biosorbents show different $\mathrm{pHzpc}$ values may be due to the presence or absences of acidic groups. These groups decrease with increasing carbonization temperature. However, during the burning of adsorbent, acidic metal oxides formed on the adsorbent surface. The pHzpc value of an aqueous solution plays an important role in the surface charge of the biosorbent.

\section{1. 2. SEM Analysis}

Fig. 2 (a)-(d) show the SEM images of ACP-250 and ACP-500, and reveal a rough surface with porous and crystalline structure for both biosorbents, which may be favorable for fluoride adsorption. The morphology of the two biosorbents was different, because of the thermal treatment at different temperatures. Furthermore, the adsorption of fluoride ion onto ACP-250 and ACP-500 was established by EDX analysis. Fig. 2 (e) and (f) show the EDX spectra of ACP-250 and ACP-500, which indicate
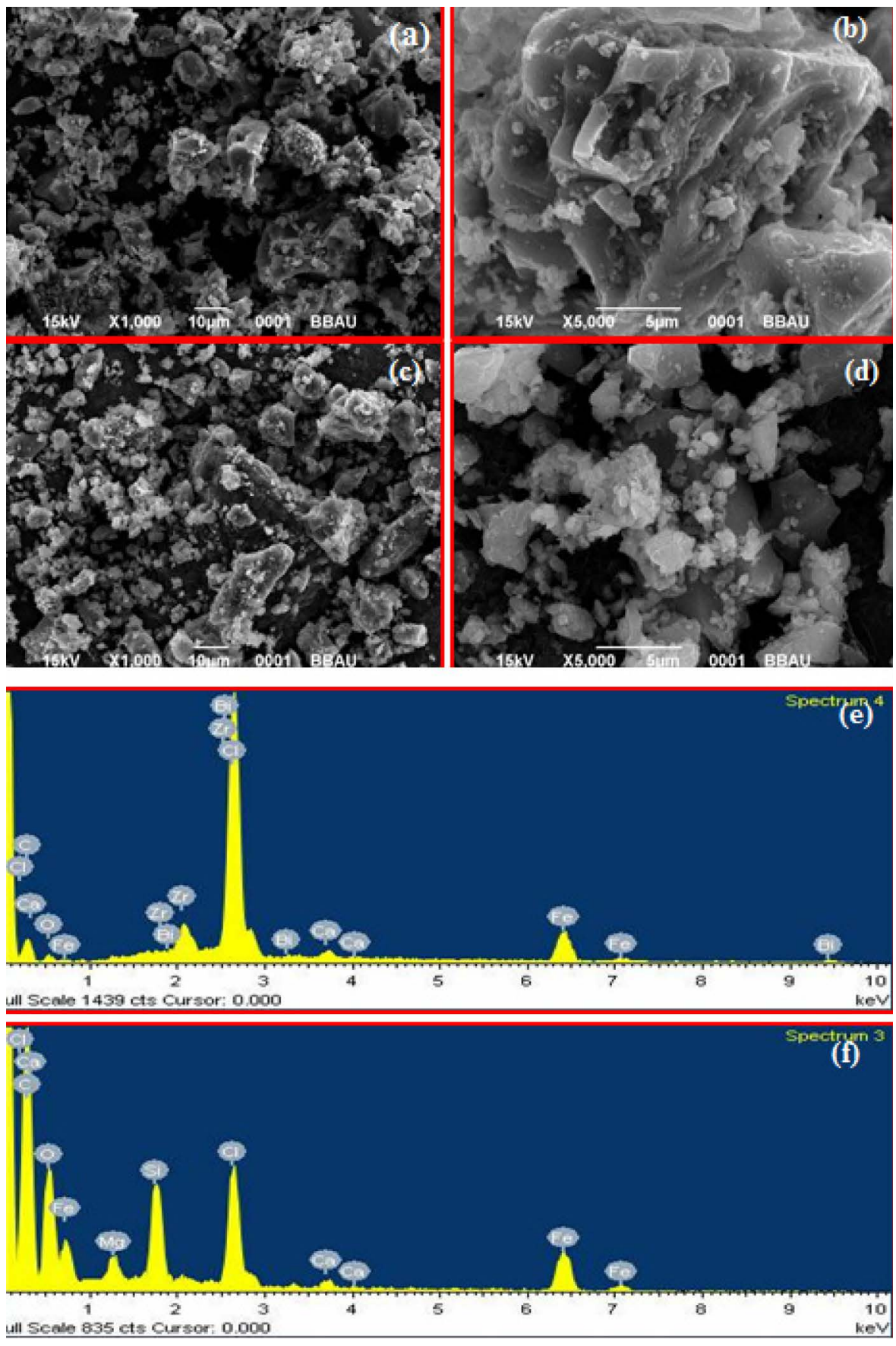

Figure 2. SEM images of (a) and (b) ACP-250, (c) and (d) ACP-500; and EDX spectra of (e) ACP-250, and (f) ACP-500. 
the higher percentage of carbon in ACP- 500 (57.98\%), as compared to ACP-250 (50.27\%). Iron was present in both materials, and Table S1 shows the weight percentage of ACP.

\section{1. 3. FTIR analysis of biosorbent}

The FT-IR spectra of ACP-250 and ACP-500 display numerous characteristic peaks. Figures 3 (a) and (b) show the FTIR spectra of ACP before and after fluoride adsorption, which display a number of adsorption peaks in the range $(4,000-500) \mathrm{cm}^{-1}$, which confirm the presence of different functional groups on the surface of biosorbents. The broad band peaks at $(3,320.0-3,340.0) \mathrm{cm}^{-1}$ were attributed to stretching vibrations in the hydroxyl group. ${ }^{27}$ The peaks that occur in the range $(2,852.0-3,000.0) \mathrm{cm}^{-1}$ were attributed to $-\mathrm{C}-\mathrm{H}$ stretching in the hetero aromatic ring, with both alkyl and ethylene group in the side chain. Symmetric C-H stretching vibration of aliphatic acid is indicated by peaks at $2,921.9 \mathrm{~cm}^{-1} .{ }^{28}$ The peaks located in

(a)

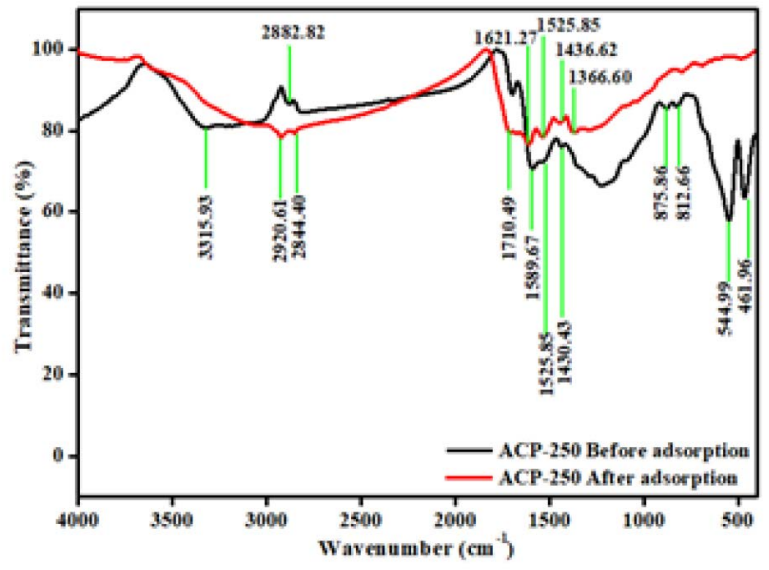

the range $(1,690.0-1,710.0) \mathrm{cm}^{-1}$ relate to the asymmetric stretching vibration of the ionic carboxylic group $\left(-\mathrm{COO}^{-}\right.$ ). ${ }^{27}$ Wavenumber ranges from $1033-1500 \mathrm{~cm}^{-1}$ represents $\mathrm{C}-\mathrm{N}$ streching in aromatic amines, $\mathrm{CH}_{2}-\mathrm{O}-\mathrm{O}$ stretching in primary alcohol, $\mathrm{OH}$ group of carboxylic acids and $\mathrm{CF}_{3}$ group attached to benzene ring. ${ }^{29}$ The sharp peak at (500$800) \mathrm{cm}^{-1}$ was related to the $\mathrm{C}-\mathrm{O}{ }^{30}$ and metal-oxygen $(\mathrm{Fe}-\mathrm{O})$ bonds ${ }^{31}$. The presence of $\mathrm{Fe}-\mathrm{O}$ band spectra before and after adsorption shows the $\mathrm{Fe}_{3} \mathrm{O}_{4}$ group. Fig.3(b) shows the FTIR spectra of ACP-500 and it was observed that the change in the intensity of the peaks confirms the adsorption of fluoride.

\section{1. 4. XRD Analysis}

Figure $3 \mathrm{c}$ shows the X-Diffraction patterns of ACP250 and ACP-500. Different diffraction peaks are observed on ACP-500, which indicate its crystalline structure; however, in the case of ACP-250, the absence of diffraction peaks is observed, which indicates its amorphous structure.

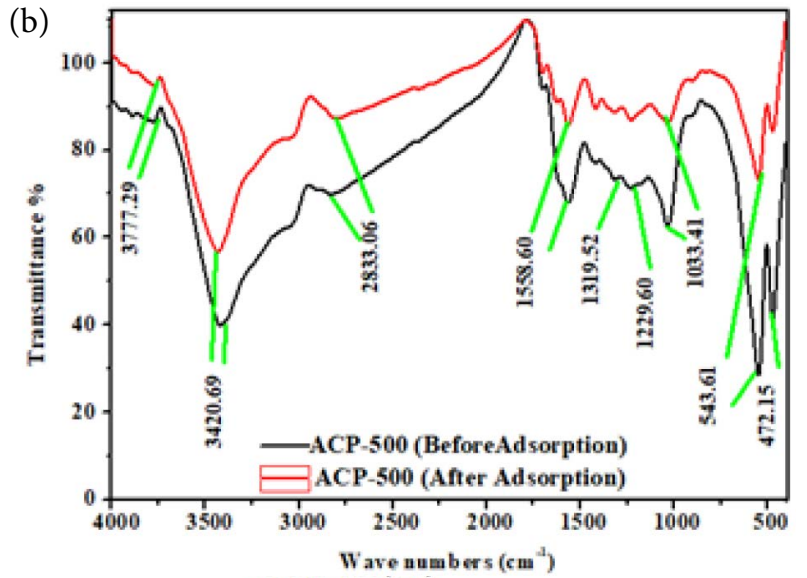

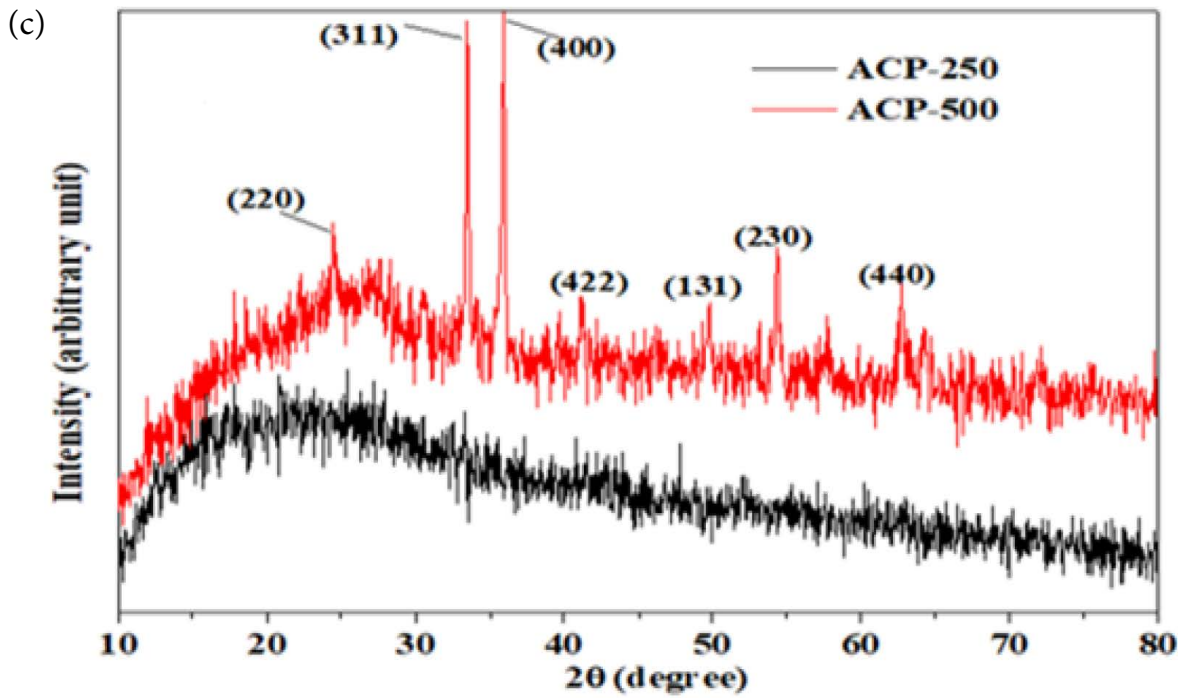

Figure 3. FTIR spectra of (a) and (b) before adsorption and after adsorption of ACP-250 and ACP-500, and (c) XRD spectra of ACP-250 and ACP500 . 
Consequently, the removal of fluoride from water by applying ACP-500 was found to be higher than that by ACP-250. The XRD pattern of ACP-500 reveals peaks at $2 \theta=(24.55$, $33.52,36.04,41.23$, and $62.77^{\circ}$ ) that were assignable by their indices (220), (311), (400), (422), and (440), respectively. ${ }^{32-33}$ All these peaks are in accord with the database in JCPDS file (82-1533), and represent the iron oxides (for example $\mathrm{Fe}_{3} \mathrm{O}_{4}$ ). The diffraction peaks at (49.88 and 54.29) corresponding to the (131) and (230) planes, respectively, represent $\mathrm{Fe}_{3} \mathrm{C}$. Carbides of iron may be classified into two categories on the basis of the location of carbon atoms present either in trigonal-prismatic interstices $\left(\mathrm{Fe}_{3} \mathrm{C}\right.$ and $\mathrm{Fe}_{5} \mathrm{C}_{2}$ ), or octahedral interstices (e.g., $\mathrm{Fe}_{2} \mathrm{C}, \mathrm{Fe}_{2.2} \mathrm{C}$ ). The formation of the carbides may increase the mechanical strength of the synthesized nano/micro size material. ${ }^{34}$

\section{2. Fluoride Adsorption Study}

\section{2. 1. Effect of Contact Time}

Figures S1 (a)-(d) show the removal percentage of ACP-250 and ACP-500 toward fluoride ion with time. It was observed that in the first 30 minute of contact time, about (35 and 58.5)\% fluoride adsorption was observed by ACP-250 and ACP-500, respectively; and afterward, the adsorption rate slowed down with contact time. During the early stage of the adsorption experiment, many vacant sites are available on the surface of the adsorbent for the removal of fluoride. After a certain period of time, fluoride ion is difficult to attach to the surface of the adsorbent, because of the repulsive force between the adsorbed fluoride ion on the surface, and fluoride ion in the aqueous solution. The removal of fluoride increased along with time, and then progressively reached equilibrium at $180 \mathrm{~min}$. Therefore, $180 \mathrm{~min}$ is considered the minimum contact time to maximum removal of fluoride from the water. A similar result was also reported by Dwivedi ${ }^{35}$ and Singh and Majumder. ${ }^{36}$

\section{2. 2. Effect of the Amount of Biosorbents}

The removal of fluoride ions by ACP-250 and ACP500 was performed at different adsorbent doses i.e. $(0.5,1.0$, 2.0 , and 3.0) $\mathrm{g} / \mathrm{L}$, while keeping all other parameters constant, such as $\mathrm{pH}(6.6 \pm 0.5)$, initial fluoride concentration $10 \mathrm{mg} / \mathrm{L}$, temperature $25{ }^{\circ} \mathrm{C}$, with different time intervals i.e. $30,60,120,180,240$, and $300 \mathrm{~min}$. Figures S1 (c) and (d) indicates the removal percentage of fluoride of both of the adsorbents. The adsorption of fluoride by adsorbent was observed to be increases from 32.5 to $47 \%$ for $0.5 \mathrm{~g} / \mathrm{L}$, and the maximum removal was observed $70 \%$ in case of $1.0 \mathrm{~g} / \mathrm{L}$. While in the case of 2.0 and $3.0 \mathrm{~g} / \mathrm{L}$, the adsorption removal gradually decrease from 41 to $29.5 \%$ and 49.2 to $39 \%$, respectively for both the bioadsorbents. The highest removal percentage was shown for both bioadsorbents at $1.0 \mathrm{~g} / \mathrm{L}$ dosage. The increase of the percentage of fluoride removal with increasing biosorbent dose might be due to the avail- ability of more active site on the adsorbents surface for the binding of fluoride ions with the increased surface area, ${ }^{37}$ While further increase of the biosorbent dose, the removal percentage was not increased, because of the partial aggregation of biomass, which resulted in decrease in the active surface area of both biosorbents for the adsorption. ${ }^{38}$

\section{2. 3. The Effect of $\mathrm{pH}$ Values}

The $\mathrm{pH}$ of a solution is a critical aspect that affects the adsorption process, due to its close relationship with the surface charge of the biosorbents, and the ionization potential of fluoride ion; therefore fluoride adsorption on adsorbent was performed at different $\mathrm{pH}$ values ranging (4-10), while keeping all other parameters constant. The required $\mathrm{pH}$ was adjusted by adding $0.1 \mathrm{~N} \mathrm{NaOH}$ or 0.1 $\mathrm{N} \mathrm{HCl}$. Fig. S1 (b) shows the effect of $\mathrm{pH}$ on the removal of fluoride. The result shows that the adsorption of fluoride on ACP-250 and ACP-500 observed a maximum of 76.5 and $74 \%$ respectively, at $\mathrm{pH} 4$. It was perceived that the removal of fluoride is extremely sensitive to the change in $\mathrm{pH}$ of the solution. It was also observed that fluoride adsorption decreased approximately (44 and 26.4) \% for ACP-250 and ACP-500, respectively, with increasing $\mathrm{pH}$ of the solution from (4 to 10). Fluoride adsorption decreases may be due to the following facts: (i) the negative charge increased on the surface of adsorbent as increased $\mathrm{pH}$ (> pHzpc is around 3.0 for both adsorbents) of solution, which reduces adsorption of the fluoride ions due to electrostatic repulsion; and (ii) enhancement of $\mathrm{OH}$ - ions reduces the adsorption of fluoride ions, as it increases the competition for adsorption sites. ${ }^{39}$

\section{2. 4. Effect of Various Fluoride Concentrations on the Adsorption Process}

The effects of various fluoride concentrations on its removal were studied at different concentrations in the range $(1-30) \mathrm{mg} / \mathrm{L}$ with keeping all the other parameters constant, such as $\mathrm{pH}(6.6 \pm 1)$, temperature $(25 \pm 1){ }^{\circ} \mathrm{C}$, with different time intervals i.e. $30,60,120,180,240$, and 300 min, and shaking speed 100 rpm. Fig. 4 (a) and (b) show the removal percentage of fluoride. The results show that when an initial concentration of fluoride increased from (1 to 30$) \mathrm{mg} / \mathrm{L}$, the removal percentage decreased from $(80$ to 24$) \%$ for ACP-250, and (86 to 38.33 ) \% for ACP-500. This might have happened because of the fixed number of active sites of the adsorbent, which might be saturated at a certain concentration.

\section{2. 5. Effect of Temperature}

Temperature is an essential parameter for the adsorption mechanism. Temperature determines the type of relations between the biosorbent and fluoride ions. If the removal percentage decreases with enhancing the tempera- 

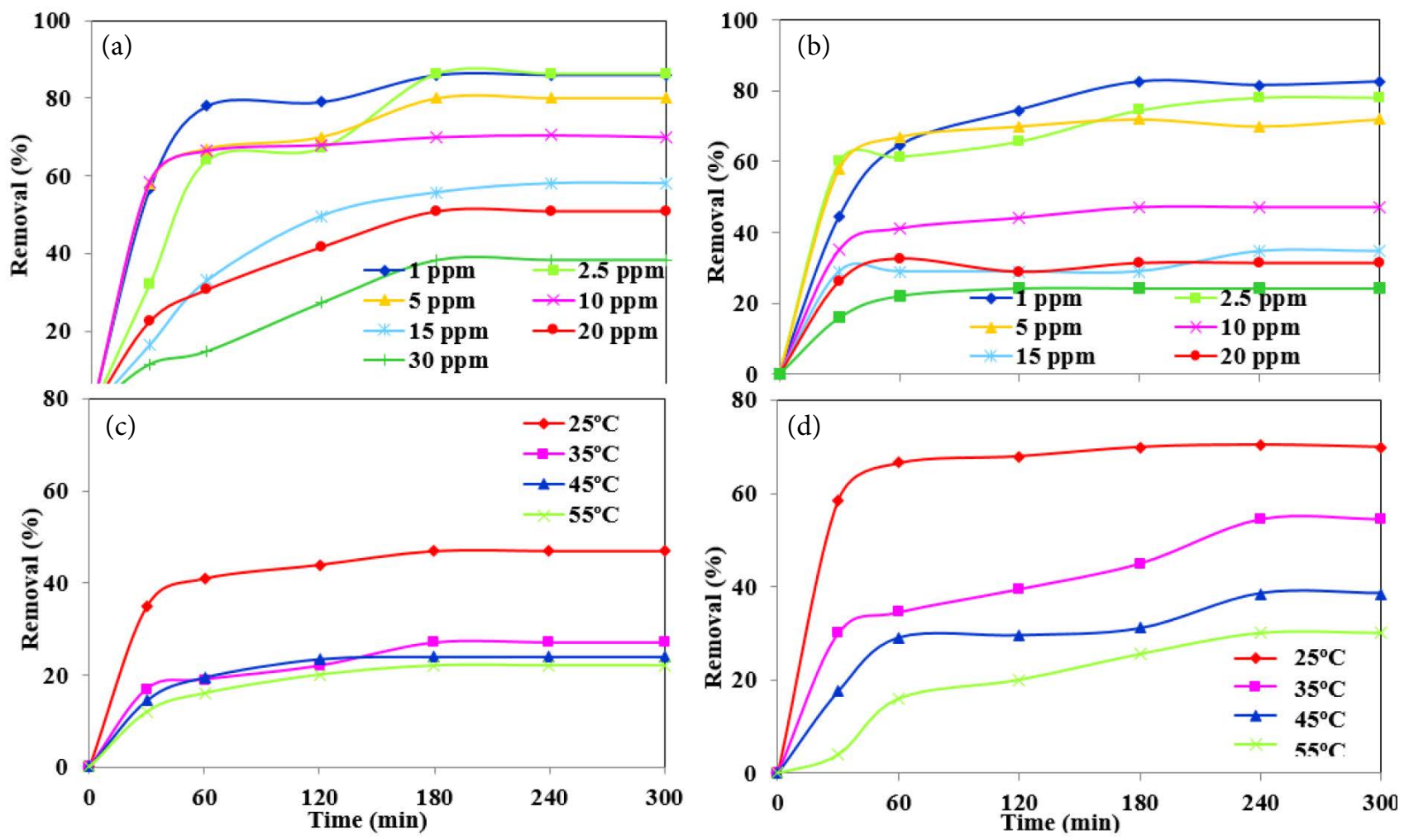

Figure 4. Effect of various parameters (a) and (b) initial fluoride concentration, (c) and (d) temperature of ACP-250 and ACP-500 for the removal of fluoride.

ture, this may represent physical adsorption or exothermic process $^{2}$. In the present study, the impact of temperature on fluoride adsorption by ACP-250 and ACP-500 was studied at four different temperatures of $(25,35,45$, and 55$){ }^{\circ} \mathrm{C}$, while keeping all the other parameters constant. Fig. 4 (c) and (d) show the removal percentage of fluoride. The removal percentage of fluoride was observed to decrease with increase of the temperature of the solution. This represents that the fluoride removal from aqueous solution by both biosorbents is an exothermic process. ${ }^{40}$ Further it is proved by thermodynamic studies at section 3.5 .

\section{3. Adsorption Isotherm Studies}

An adsorption isotherm defines the interaction between pollutant and adsorbent with adsorption properties and equilibrium information at equilibrium, a point where no further adsorption take place. To understand the nature of the interaction between the adsorbent and amount of adsorbate at a constant temperature, the adsorption isotherm is applied. ${ }^{21}$ In the present work, to understand the adsorption behavior, the Langmuir and Freundlich isotherm model were applied. ${ }^{41-42}$

\section{3. 1. Langmuir Isotherm Model}

The Langmuir adsorption isotherm model describes a monolayer with homogeneous adsorption, in which all sites of the adsorbent hold an equal affinity for the pollutant. ${ }^{43}$ This model also describes an equilibrium saturation point, where no further adsorption can take place. ${ }^{44-45}$ The monolayer adsorption model is given as Eq. (3).

$$
\frac{C_{e}}{q_{e}}=\frac{1}{Q_{0}}+\frac{1}{b Q_{0} C_{e}}
$$

where, $\mathrm{q}_{\mathrm{e}}$ is the amount of $\mathrm{F}^{-}$adsorbed per unit mass of adsorbent $\left(\mathrm{mg} \mathrm{g}^{-1}\right) ; \mathrm{Q}_{0}$ and $\mathrm{b}$ are the Langmuir constant concerning the adsorption capacity $(\mathrm{mg} / \mathrm{g})$ and the binding energy constant $(\mathrm{L} / \mathrm{mg})$, respectively. The values of $\mathrm{Q}_{0}$ and $\mathrm{b}$ can be obtained using linear plot between $\mathrm{C}_{\mathrm{e}} / \mathrm{q}_{\mathrm{e}}$ and $1 / \mathrm{C}_{\mathrm{e}}$ at different fluoride concentrations (Figs. $5 \mathrm{a}$ and $\mathrm{b}$ ). The Langmuir isotherm is stated as a dimensionless constant $\left(\mathrm{R}_{\mathrm{L}}\right)$, and also denoted as a separation factor that can be calculated by applying the following equation.

$$
R_{L}=\frac{1}{1+b C_{0}}
$$

Where, $\mathrm{C}_{\mathrm{o}}$ is the initial fluoride concentration $(\mathrm{mg}$ $\mathrm{L}^{-1}$ ), and the value of $\mathrm{R}_{\mathrm{L}}$ indicates the adsorption process i.e. if the value of $R_{L}$ lies between 0 and 1, then the adsorption process is favorable, $R_{L}=1$ signifies linear adsorption; if $R_{L}=0$, the adsorption process is irreversible; and $\mathrm{R}_{\mathrm{L}}>1$ represents uncomplimentary adsorption, while favorable $\left(0<\mathrm{R}_{\mathrm{L}}<1\right)$. Table 1 shows the $\mathrm{R}_{\mathrm{L}}$ values $\left(0<\mathrm{R}_{\mathrm{L}}<1\right)$ for both materials. 


\section{3. 2. Freundlich Isotherm Model}

The Freundlich adsorption isotherm describes the reversible, as well as non-ideal, adsorption. This model has been used only for multilayer adsorption with different binding energy spectra. The linear form of the Freundlich isotherm equation is given below:

$$
\log q_{e}=\log K_{F}+\frac{1}{n} \log C_{e}
$$

Where, $\mathrm{K}_{\mathrm{f}}$ and $n$ are the Freundlich isotherm constants that represent the adsorption capacity and adsorption intensity of the fluoride ions on the biosorbents. These values can be obtained from the linear plot of $\ln$ $\mathrm{q}_{\mathrm{e}}$ vs. $\ln \mathrm{C}_{\mathrm{e}}$. The values of the Freundlich constants
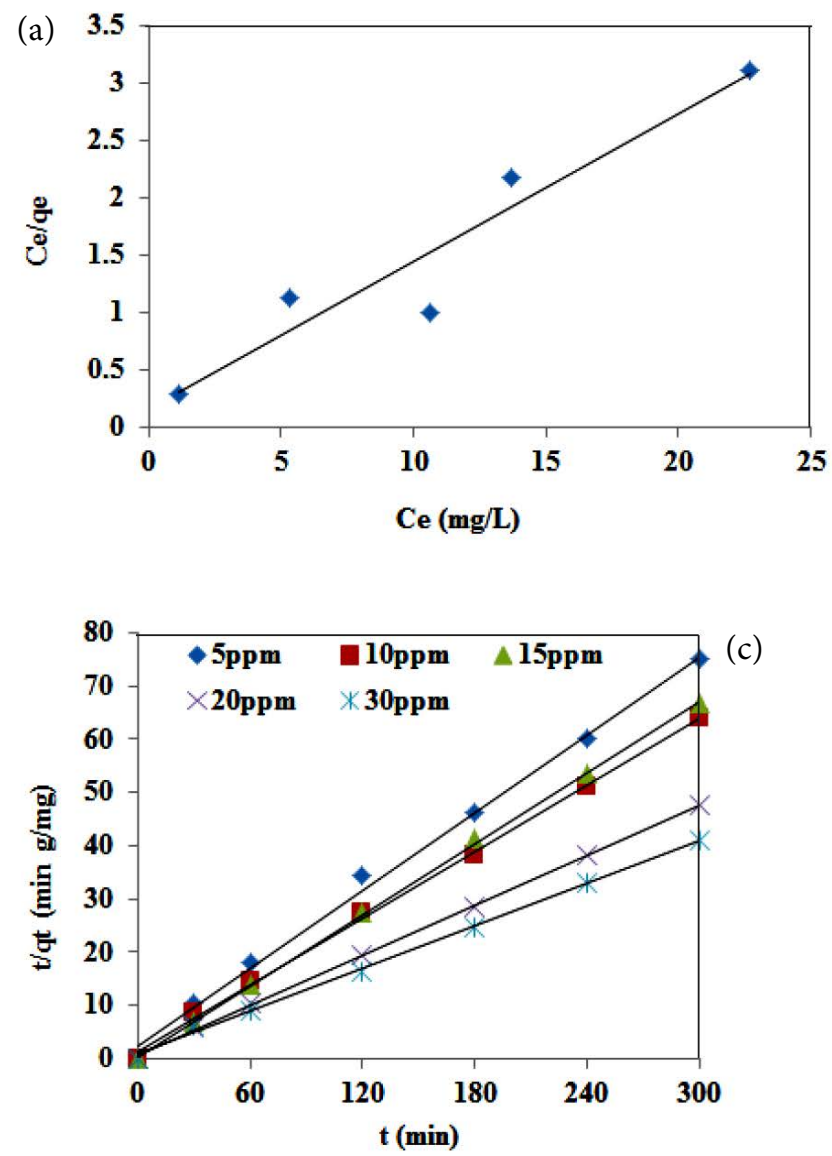

\section{4. 1. Kinetics Studies}

Adsorption kinetics studies describe the adsorption rate and mechanism of fluoride adsorption on biosorbents. Two different types of kinetics model viz, the Lagergren first-order kinetics model and the pseudo second kinetics model were applied to understand the kinetics of fluoride adsorption. The Lagergren pseudo- first-order by Ho and McKay ${ }^{46}$ and pseudo second kinetics model ${ }^{47}$ are expressed as Eqs. (6) and (7), respectively.

$$
\begin{aligned}
& \log \left(q_{e}-q_{t}\right)=\log q_{e}-\frac{k_{1} t}{2.303} l \\
& \frac{t}{q_{t}}=\frac{1}{k_{2} q_{e} 2}+\frac{t}{q_{e}}
\end{aligned}
$$
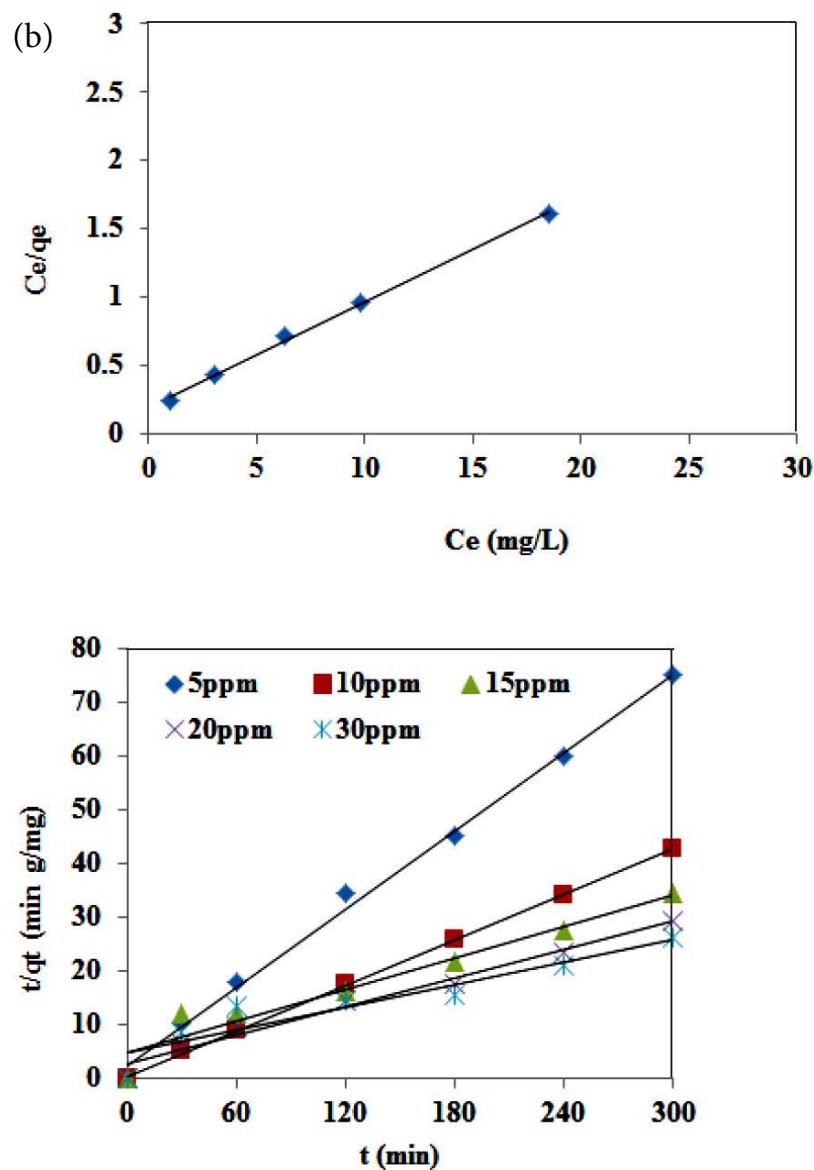

Figure 5. Adsorption isotherm and kinetics of fluoride onto ACP-250 and ACP-500 for (a) and (b) the Langmuir isotherm, and (c) and (d) second order kinetics.

$\mathrm{K}_{\mathrm{f}}$ are (3.5886 and 4.2833) for ACP-250 and ACP500 , respectively. Table 1 shows that the values of $1 / \mathrm{n}$ are (5.4347 and 2.7593) for ACP- 250 and ACP-500, respectively. The results show that fluoride adsorption follows the monolayer Langmuir isotherms $\left(\mathrm{R}^{2}=0.9772\right.$ for $\mathrm{ACP}-250$, and 0.9963 for ACP-500). where, $k_{1}$ and $k_{2}$ are the rate constants of the pseudo first order and pseudo second order kinetics, respectively; $\mathrm{q}_{\mathrm{e}}$ $\left(\mathrm{mg} \mathrm{g}^{-1}\right)$ is the adsorption capacity of the biosorbent at equilibrium, and $\mathrm{q}_{\mathrm{t}}\left(\mathrm{mg} \mathrm{g}^{1}\right)$ is the amount of fluoride adsorbed on the adsorbent surface at time $t\left(\mathrm{~min}^{-1}\right)$. The values of $k_{1}, k_{2}$, and $q_{e}$ were obtained from the linear plot of $\log \left(\mathrm{q}_{\mathrm{e}}-\mathrm{q}_{\mathrm{t}}\right)$ vs. $\mathrm{t}$ and $\mathrm{t} / \mathrm{q}_{\mathrm{t}}$ vs. $\mathrm{t}$. 
Table 1: Isotherms Parameters for adsorption of fluoride on the ACP-250 and ACP-500

\begin{tabular}{lccc}
\hline Isotherms & Parameters & \multicolumn{2}{c}{ Values } \\
\hline Langmuir & & ACP-250 & ACP-500 \\
\cline { 2 - 4 } & $\mathrm{Q}_{\mathrm{O}}(\mathrm{mg} / \mathrm{g})$ & 7.5757 & 12.6262 \\
& $\mathrm{~b}(\mathrm{~L} / \mathrm{mg})$ & 0.4404 & 0.4634 \\
& $\mathrm{R}_{\mathrm{L}}$ & 0.6942 & 0.6833 \\
\cline { 2 - 4 } Freundlich & $\mathrm{R}^{2}$ & 0.9772 & 0.9963 \\
& $\mathrm{k}_{\mathrm{f}}(\mathrm{mg} / \mathrm{g})$ & 2.2344 & 3.2433 \\
& $\mathrm{~N}$ & 2.4324 & 1.9531 \\
& $\mathrm{R}^{2}$ & 0.9353 & 0.9513 \\
\hline
\end{tabular}

Table 2 lists the results of the Lagergren first-order kinetics and pseudo second kinetics model (Figures 5 ( $\mathrm{c}$ and d)) and their regression coefficient $\left(\mathrm{R}^{2}\right)$. Pseudo-First-order theoretical adsorption capacity $(\mathrm{mg} / \mathrm{g})$ of fluoride was increased from $0.83 \mathrm{mg} / \mathrm{g}$ to $7.3 \mathrm{mg} / \mathrm{g}$ for ACP-250 and from $0.57 \mathrm{mg} / \mathrm{g}$ to $11.6 \mathrm{mg} / \mathrm{g}$ for ACP-500 with increasing concentration of fluoride from $1 \mathrm{mg} / \mathrm{L}$ to $30 \mathrm{mg} / \mathrm{L}$. However, pseudo-second-order theoretical adsorption capacity $(\mathrm{mg} / \mathrm{g})$ of fluoride was also increased for both adsorbents ACP-250 and ACP-500, adsorption capacity for ACP-250 was almost similar to pseudo-first-order theoretical adsorption capacity. However, it was increased from 0.89 $\mathrm{mg} / \mathrm{g}$ to $14.3 \mathrm{mg} / \mathrm{g}$ for ACP-500 with increasing concentration of fluoride from $1 \mathrm{mg} / \mathrm{L}$ to $30 \mathrm{mg} / \mathrm{L}$. In comparison of the two models, the pseudo-second-order kinetics model fitted well with the adsorption data, as compared to the pseudo-first order kinetics model.

\section{4. 2 Intra-Particle Diffusion Model (IPDM)}

IPDM represents the three steps for the adsorption of contaminant on to the surface of adsorbent, ${ }^{48}$ in the

Table 2: Kinetics parameters of Pseudo first, Pseudo second and Intraparticle diffusion model for fluoride adsorption on ACP-250 and ACP-500

\section{Pseudo First Order}

\begin{tabular}{|c|c|c|c|c|c|c|}
\hline \multicolumn{4}{|c|}{ ACP-250 } & \multicolumn{3}{|c|}{ ACP-500 } \\
\hline $\mathrm{Co}(\mathrm{mg} / \mathrm{L})$ & $\mathrm{Qe}\left(\mathrm{mg} \mathrm{g}^{-1}\right)$ & $\mathrm{k}_{1 \text { ads }}\left(\min ^{-1}\right)$ & $\mathbf{R}^{2}$ & $\mathrm{Qe}\left(\mathrm{mg} \mathrm{g}^{-1}\right)$ & $\mathrm{k}_{1 \text { ads }}\left(\min ^{-1}\right)$ & $\mathbf{R}^{2}$ \\
\hline 1 & 0.825 & -0.00326 & 0.9091 & 0.5757 & -0.0039 & 0.8007 \\
\hline 2.5 & 0.825 & -0.00287 & 0.6926 & 1.8513 & -0.0024 & 0.8405 \\
\hline 5 & 3.6 & -0.00243 & 0.6608 & 2.5153 & -0.003 & 0.7729 \\
\hline 10 & 4.7 & -0.00408 & 0.8914 & 3.8010 & -0.0053 & 0.8425 \\
\hline 15 & 5.2 & -0.00126 & 0.3642 & 10.0855 & -0.0034 & 0.9923 \\
\hline 20 & 6.3 & -0.00343 & 0.7567 & 9.4566 & -0.0026 & 0.9901 \\
\hline 30 & 7.3 & -0.0076 & 0.9957 & 11.6064 & -0.0019 & 0.9787 \\
\hline
\end{tabular}

Pseudo Second Order

\begin{tabular}{lcccccc}
\hline \multicolumn{3}{c}{ ACP-250 } & \multicolumn{3}{c}{ ACP-500 } \\
\hline $\mathbf{C o}(\mathbf{m g} / \mathbf{L})$ & $\mathbf{Q e}\left(\mathbf{m g ~ g}^{\mathbf{- 1}}\right)$ & $\mathbf{K}_{\mathbf{2} \text { ads }}\left(\mathbf{m i n}^{\mathbf{- 1}}\right)$ & $\mathbf{R}^{\mathbf{2}}$ & $\mathbf{Q e}\left(\mathbf{m g ~ g}^{\mathbf{- 1}}\right)$ & $\mathbf{K}_{\mathbf{2} \text { ads }}\left(\mathbf{m i n}^{\mathbf{- 1}}\right)$ & $\mathbf{R}^{\mathbf{2}}$ \\
\hline 1 & 0.825 & 0.3755 & 0.9452 & 0.8858 & 0.1288 & 0.9974 \\
2.5 & 1.865 & 0.04817 & 0.9941 & 2.3889 & 0.0135 & 0.9699 \\
5 & 3.6 & 0.07282 & 0.9992 & 4.1220 & 0.00473 & 0.9963 \\
10 & 4.7 & 0.03008 & 0.9986 & 7.1022 & 0.04044 & 0.9996 \\
15 & 5.2 & 0.01738 & 0.9952 & 10.2040 & 0.00204 & 0.9391 \\
20 & 6.3 & 0.05227 & 0.9984 & 11.2612 & 0.00293 & 0.9765 \\
30 & 7.3 & 0.02057 & 0.9978 & 14.3061 & 0.00095 & 0.8763 \\
\hline
\end{tabular}

Intraparticle Diffusion

\begin{tabular}{|c|c|c|c|c|c|c|}
\hline \multicolumn{4}{|c|}{ ACP-250 } & \multicolumn{3}{|c|}{ ACP-500 } \\
\hline $\mathrm{Co}(\mathrm{mg} / \mathrm{L})$ & $\operatorname{Kid}\left(\mathrm{mg} \mathrm{g}^{1} \mathrm{~min}^{-1}\right)$ & $\mathrm{C}\left(\mathrm{mg}^{-1}\right)$ & $\mathbf{R}^{2}$ & $\operatorname{Kid}\left(\operatorname{mg~g}^{1} \min ^{-1}\right)$ & $\mathrm{C}\left(\mathrm{mg}^{-1}\right)$ & $\mathbf{R}^{2}$ \\
\hline 1 & 0.0478 & 0.076 & 0.9302 & 0.0456 & 0.2146 & 0.7769 \\
\hline 2.5 & 0.0998 & 0.4898 & 0.7837 & 0.1299 & 0.2019 & 0.9157 \\
\hline 5 & 0.1774 & 1.1369 & 0.6774 & 0.2088 & 1.0068 & 0.7863 \\
\hline 10 & 0.2429 & 1.2854 & 0.7534 & 0.3452 & 2.2925 & 0.6642 \\
\hline 15 & 0.2459 & 1.4985 & 0.6932 & 0.5522 & 0.2456 & 0.9445 \\
\hline 20 & 0.3027 & 2.1699 & 0.6187 & 0.6149 & 0.9012 & 0.6645 \\
\hline 30 & 0.3894 & 1.8909 & 0.7581 & 0.7478 & 0.2924 & 0.9547 \\
\hline
\end{tabular}


first step, adsorbate is adsorb onto the surface of adsorbent through the external surface or prompt adsorption process; in the second step steady adsorption step which shows the controlled intraparticle diffusion, and in the third step, adsorbate transfers from larger pore to micropores consequently decrease in adsorption rate and finally attaining equilibrium step. Another kinetics model including IPDM has also described the mechanism of fluoride adsorption by the adsorbent. The IPDM was proposed by Weber and Morris ${ }^{49}$ by Eq. (8):

$$
\mathbf{q}_{\mathbf{t}}=\mathbf{K}_{\mathrm{id}} \mathbf{t}^{1 / 2}+\mathbf{C}
$$

Where, $\mathrm{K}_{\mathrm{id}}\left(\mathrm{mg} \mathrm{g}^{-1} \mathrm{~min}^{-1}\right)$ is the Intraparticle diffusion rate constant, $\mathrm{C}\left(\mathrm{mg} \mathrm{g}^{-1}\right)$ is the thickness of the boundary layer, and the values of $\mathrm{K}_{\mathrm{id}}$ and $\mathrm{C}$ are calculat-

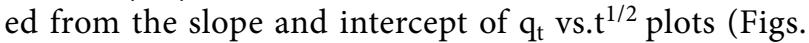
S2 (a) and (b)), respectively. Table 2 shows the obtained value. According to IPDM, if the adsorption of a solute is controlled by the intra-particle diffusion process, a plot of $\mathrm{q}_{\mathrm{t}}$ versus $\mathrm{t}^{1 / 2}$ passes through the origin. Therefore, it was concluded that intraparticle diffusion are involved in the adsorption of Fluoride onto ACP-250 and ACP-500.

\section{5. Study of Adsorption Thermodynamics}

The thermodynamics parameters could be responsible for comprehensive information about the essential energy and structural change after adsorption. The thermodynamics parameters were calculated as Eqs. (9)(10): the change in Gibbs free energy $\left(\Delta \mathrm{G}^{\circ}\right)\left(\mathrm{KJ} \mathrm{mol}^{-1}\right)$, where $\Delta H$ is the change in enthalpy and $\Delta S^{\circ}$ is the change in entropy.

$$
\begin{aligned}
& K_{c}=\frac{q_{e}}{C_{e}} \\
& \Delta \mathrm{G}=-R T \ln K \\
& \ln K_{c}=\frac{\Delta \mathrm{S}}{R}-\frac{\Delta \mathrm{H}}{R T}
\end{aligned}
$$

where, $\mathrm{K}_{\mathrm{c}}$ is the equilibrium constant, $\mathrm{q}_{\mathrm{e}}$ is the quantity $(\mathrm{mg} / \mathrm{g})$ of fluoride adsorbed on the surface of biosorbent at equilibrium, $\mathrm{C}_{\mathrm{e}}$ represents the equilibrium concentration of fluoride in a solution $(\mathrm{mg} / \mathrm{L})$, and $\mathrm{R}$ denotes the universal gas constant $(8.314 \mathrm{~J} / \mathrm{mol} \mathrm{K})$, while $\mathrm{T}$ is the absolute temperature $(\mathrm{K})$ respectively. Fluoride adsorption experiments were completed at different temperatures of $(25,35$, 45 , and 55$){ }^{\circ} \mathrm{C}$, and showed that the removal percentage of fluoride decreased with increased absolute temperature. The changes in enthalpy and entropy were calculated from the plot of $\ln \mathrm{Kc}$ vs. 1/T, which are shown in Fig. S2 (c) and (d), and Table S2 gives the obtained values. The results show that the adsorption of fluoride depends on temperature. The negative value of $\Delta \mathrm{G}^{\circ}$ for ACP-250 represents a non-spontaneous process; however, the value of $\Delta \mathrm{G}^{\circ}$ for ACP-500 specifies that the adsorption process favorable at (25 and 35) ${ }^{\circ} \mathrm{C}$ temperature. ${ }^{50}$ The process of thermodynamics was exothermic which was confirmed by the negative value of $\Delta \mathrm{H}^{\circ}$ and $\Delta \mathrm{S}^{\circ}$ means the adsorption decreases with increase in temperature. The opportunity for favorable adsorption can be represented by the negative value of $\Delta S^{\circ}$ for both the bioadsorbents. ${ }^{51}$

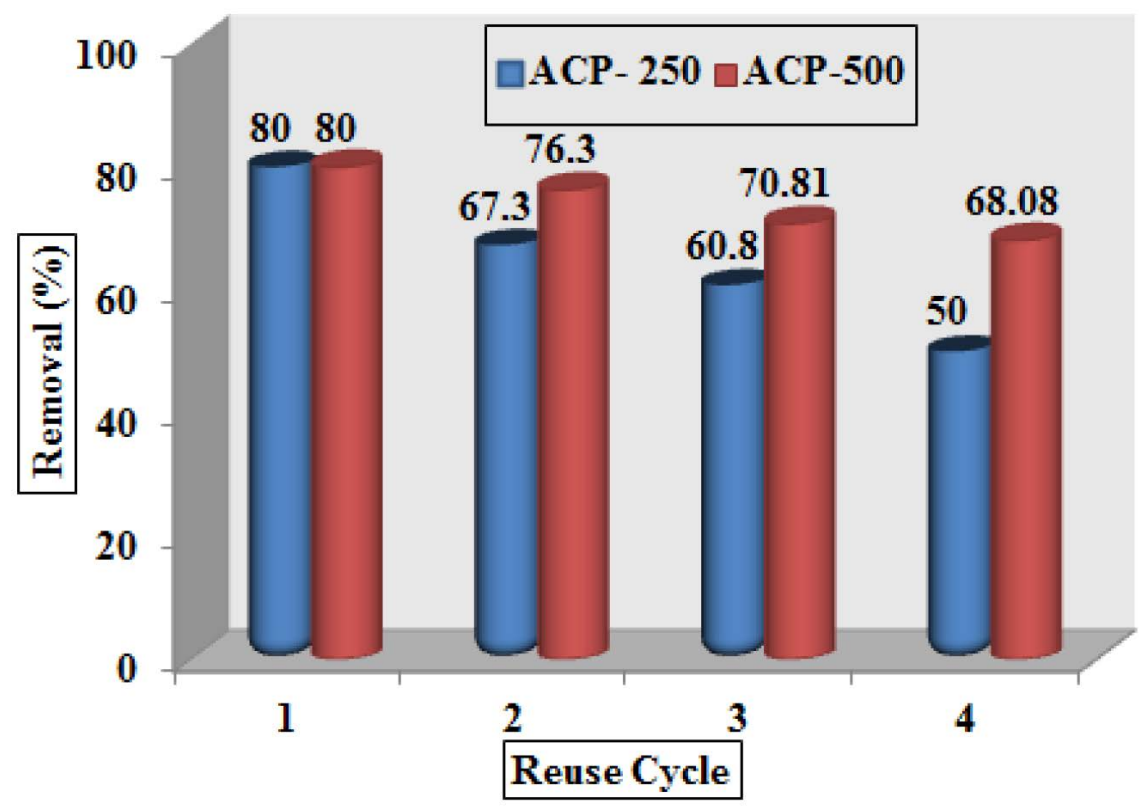

Figure 6. Reusability potential of the synthesized biosorbents (ACP-250 and ACP-500). 


\section{Regeneration Stability Test}

The adsorption and desorption efficiency are the significant characteristics of an adsorbent. The reproducibility of an adsorbent decreases its overall cost, hence increases its value in the continuous batch experiment. The desorption of fluoride from ACP-250 and ACP-500 for the regeneration of active site was performance in $0.1 \mathrm{M}$ sodium hydroxide $(\mathrm{NaOH})$ solution as a desorbing agent for two hours; the adsorbent was then washed with distilled water, until the solution $\mathrm{pH}$ became neutral. The regenerated adsorbents (ACP-250 and ACP-500) were tested for fluoride removal from aqueous solution. The regeneration experiment was conducted with a concentration of $5.0 \mathrm{mg}$ $\mathrm{L}^{-1}$ of aqueous fluoride solution during the beginning of every cycle. Fig. 6 shows the results of reusability. For the $\left(1^{\text {st }} 2^{\text {nd }}, 3^{\text {rd }}\right.$, and $\left.4^{\text {th }}\right)$ cycle, the removal efficiencies of ACP500 were $(80,76.3,70.81$, and 68.08$) \%$; however for ACP250 , they were $(80,67.3,60.8$, and 50$) \%$, respectively. The results clearly show that both biosorbents can be reused effectively to remove fluoride ion from water. However, ACP-500 has higher regeneration efficiency, as compared to ACP-250.

\section{Comparison of the Fluoride Adsorption Capacity of ACP and other Biomass-Based Absorbents}

Comparisons of the maximum fluoride adsorption capacity of ACP-250 and ACP-500 with a wide variety of adsorbent have been reported. Table 3 shows that the Langmuir adsorption capacity of fluoride was (7.58 and 12.63) $\mathrm{mg} / \mathrm{g}$ ) using ACP-250 and ACP-500, respectively, which values are higher than those of activated alumina, wheat straw raw, original tea, Moringa indica based activated carbon, activated bagasse carbon, biomass carbon at

Table 3: Comparison of the defluoridation capacities of different biomass based sorbents

\begin{tabular}{|c|c|c|}
\hline Adsorbent & $\begin{array}{l}\text { ption ca } \\
(\mathrm{mg} / \mathrm{g})\end{array}$ & References \\
\hline Activated alumina & 7.6 & $(\mathrm{Ku} \text { and Chiou, 2002) })^{52}$ \\
\hline Wheat straw raw & 1.9 & (Yadav et al., 2013) ${ }^{54}$ \\
\hline Original tea & 3.83 & $($ Caia et al., 2015) \\
\hline Tea-Fe & 10.47 & $\left(\right.$ Caia et al., 2015) ${ }^{55}$ \\
\hline $\begin{array}{l}\text { Moringa indica based } \\
\text { activated carbon }\end{array}$ & 0.23 & (Karthikeyan et al., 2007) \\
\hline Wheat straw raw & 1.93 & $(\text { Yadav et al., 2013) })^{54}$ \\
\hline Activated bagasse carbon & 1.15 & $(\text { Yadav et al., 2013) })^{54}$ \\
\hline Biomass carbon at $300^{\circ} \mathrm{C}$ & 0.52 & $(\text { Sinha et al., 2003) })^{57}$ \\
\hline Biomass carbon at $600^{\circ} \mathrm{C}$ & 1.54 & $(\text { Sinha et al., 2003) })^{57}$ \\
\hline Pine wood biochar & 7.66 & $(\text { Mohan et al., 2012) })^{58}$ \\
\hline ACP-250 & 7.8247 & This study \\
\hline ACP-500 & 13.0039 & This study \\
\hline
\end{tabular}

$300^{\circ} \mathrm{C}$, and biomass carbon at $600{ }^{\circ} \mathrm{C}$ based adsorbents. It requires less time (equilibrium-3hrs) to remove almost all amount of fluoride in comparison with some other studies. ${ }^{52,53}$ Removal of fluoride was not much affected by $\mathrm{pH}$ of the aqueous solution so it can be applied for the removal of fluoride from ground water as well as from wastewater of any $\mathrm{pH}$. For ACP-500 maximum $80.5 \%$ removal was observed at $\mathrm{pH} 4$ and at alkaline medium i.e. $\mathrm{pH} 8$, about $56 \%$ removal was obtained. While ACP-250 shows good results at $\mathrm{pH} 4$. As shown in the Table 3 , it was observed that the adsorbents of present study having higher adsorption capacity than other adsorbent.

\section{Cost Analysis for Fluoride Removal}

The cost of the fluoride treatment by applying biosorbents is dependent on various factors, such as the adsorption efficiency of the adsorbent, reuse capability scale of the application, etc. The present study showed some important efforts of the regeneration and reuse of ACPs in successive cycles, which indicate that ACP-250 and ACP-500 were used to remove fluoride up to four cycles. Table S3 summarizes the cost of some of the material that is used for the removal of fluoride. As the present adsorbent is cost effective and yet it is non-commercial but can be commercialized. Citrus limetta pulp alone could not be used directly as an adsorbent for fluoride removal because it leaches in the solution as well as shows negligible adsorption. Hence, modification is done to increase the removal efficiency of the material. Material developed after modification makes adsorbent magnetic and it becomes very easy to separate the adsorbent through magnet and can be recycled many times. The cost of activated carbon prepared from pulp was calculated on the basis of raw material cost and process cost.

\section{Conclusion}

Low-cost highly efficient magnetic or iron permeated activated carbon (ACP-250 and ACP-500) were synthesized from Citrus limetta pulp waste, and applied for the removal of fluoride ions from aqueous solution. FTIR analysis of ACP-250 and ACP-500 confirmed that fluoride-adsorbing groups were present on the surface of biosorbents. EDX results show that carbon was the dominant element in both biosorbents (Carbon content of 58\% in ACP-500 and 50.3\% in ACP-250. XRD results show that iron was present in the form of oxides and carbide. Slightly acidic $\mathrm{pH}$ and $25^{\circ} \mathrm{C}$ temperature were favorable for the removal of fluoride from an aqueous solution using magnetically active resource materials. Adsorption of fluoride followed the monolayer Langmuir isotherm model and pseudo-second-order kinetics. This study confirmed that ACP-500 showed higher removal efficiency of fluo- 
ride than ACP-250. It was observed that the synthesized bioadsorbent can be used up to four cycles with effective removal of fluoride and the cost analysis proved that the synthesized biogenic iron permeated activated carbon was cost effective. Therefore, waste biomass of Citrus limetta could be applied as highly proficient material for the removal of fluoride from the water.

\section{Acknowledgment}

The authors are grateful to the Science and Engineering Research Board, for providing financial support for this work (Department of Science and Technology (SERBDST) Sponsored Project No. ECR/2016/001924). Special thanks to the University Sophisticated Instrumentation Center (USIC) BBAU, Lucknow, for their kind support in the characterization of adsorbents. In addition this was partially supported by research grant-2019 of Kwangwoon University, Seoul and Republic of Korea.

\section{References}

1. M. Amini, K. Mueller, K. C. Abbaspour, T. Rosenberg, M. Afyuni, K. N. Moller, M. Sarr, C. A. Johnson, Environ. Sci. Technol. 2008, 42, 3662-3668. DOI:10.1021/es071958y

2. A. L. Srivastav, P. K. Singh, V. Srivastava, Y. C. Sharma, J. Hazard. Mater. 2013, 263, 342-352.

DOI: 1https://doi.org/10.1016/j.jhazmat.2013.04.017

3. D. Banks, C. Reimann, O. Røyset, H. Skarphagen, O. M. Saether, Appl. Geochem. 1995, 10, 1-16.

DOI:10.1016/0883-2927(94)00046-9

4. M. Edmunds, P. Smedley, Elsevier Academic Press Environ. Sci. Technol. 2005, 34, 3247-3253.

5. E. J. Reardon, Y. Wang, Environ. Sci. Technol. 2000, 34, 32473253. DOI: 1 https://doi.org/10.1021/es990542k

6. F. Shen, X. Chen, P. Gao, G. Chen, Chem. Eng. Sci. 2003, 58, 987-993. DOI:10.1016/S0009-2509(02)00639-5

7. G. Puente, J. J. Pis, J. A. Menéndez, P. J. Grange, Anal. Appl. Pyrolysis. 1997, 43, 125-138.

DOI:10.1016/S0165-2370(97)00060-0

8. W.H.O. Guidelines for Drinking Water Quality. Geneva. 2004.

9. S. Ayoob, A. K. Gupta, Environ. Sci. Technol. 2006, 36, 433487. DOI:10.1080/10643380600678112

10. B. S. Sharma, J. Agrawal, A. K. Gupta, Asian J. Environ. Biol. 2011, 2, 131-134. DOI:10.1021/ie202189

11. M. Mahramanlioglu, I. Kizilcikli, I. O. Bicer, J. Fluorine Chem. 2002, 115, 41-47. DOI:10.1016/S0022-1139(02)00003-9

12. P. T. C. Harrison, J. Fluorine Chem. 2005, 126, 1448-1456. DOI:10.1016/j.jfluchem.2005.09.009

13. X. Fan, D. J. Parker, M. D. Smith, Water Res. 2003, 37, 49294937. DOI:10.1016/j.watres.2003.08.014

14. M. G. Sujana, G. Soma, N. Vasumathi, S. Anand, J. Fluorine Chem. 2009, 130, 749-754.

DOI:10.1016/j.jfluchem.2009.06.005
15. X. Wu, Y. Zhang, X. Dou, M. Yang, Chemosphere. 2007, 69, 1758-1764. DOI:10.1016/j.chemosphere.2007.05.075

16. K. Biswas, K. Gupta, A. Goswami, U. C. Ghosh, Desalination. 2010, 255, 44-51. 10.1016/j.desal.2010.01.019.

DOI:10.1016/j.desal.2010.01.019

17. N. Viswanathan, S. Meenakshi, Appl. Clay Sci. 2010, 48, 607611. DOI:10.1016/j.clay.2010.03.012

18. R. C. Meenakshi, Maheshwari, J. Hazard. Mater. 2006, B137, 456-463. DOI:10.1016/j.jhazmat.2006.02.024

19. J. Wioeniewski, A. Rozanska, Desalination. 2007, 212, 251260. DOI:10.1016/j.desal.2006.11.008

20. S. Deng, H. Liu, W. Zhou, J. Huang, G. Yu, J. Hazard. Mater. 2011, 186, 1360-1366. DOI:10.1016/j.jhazmat.2010.12.024

21. A. Bhatnagar, E. Kumar, M. Sillanpaa, Chem. Eng. J. 2011, 171, 811-840. DOI:10.1016/j.cej.2011.05.028

22. M. Rafatullah, O. Sulaiman, R. Hashim, A. Ahmad, J. Hazard. Mater. 2010, 177(1-3), 70-80.

DOI:10.1016/j.jhazmat.2009.12.047

23. J. R. Koduru, L. P. Lingamdinne, J. Singh, K. H. Choo, Process Saf. Environ. Prot. 2016, 103, 87-96.

DOI:10.1016/j.psep.2016.06.038

24. Y. Li, N. Li, D. Chen, X. Wang, Z. Xu, D. Dong, 2009, Water, air, and soil pollut, 196(1-4), 41-49.

DOI:10.1007/s11270-008-9756-2

25. J. Singh, N. S. Mishra, S. Uma Banerjee, Y. C. Sharma, Bio. Resour. 2011, 6(3), 2732-2743.

26. H. Paudyala, B. Pangenia, K. Inouea, H. Kawakitaa, K. Ohtoa, H. Haradaa, S. Alam, J. Hazard. Mater. 2011, 192, 676-682. DOI:10.1016/j.jhazmat.2011.06.068

27. H. Li, Z. Li, T. Liu, X. Xiao, Z. Peng, L. Deng, Bioresour. Technol. 2008, 99, 6271-6279. DOI:10.1016/j.biortech.2007.12.002

28. S. Srivastavaa, S. B. Agrawala, M. K. Mondalb, Ecol. Eng. 2015, 85, 56-66. DOI:10.1016/j.ecoleng.2015.10.011

29. Lambert, J. B (1987). Macmillan, New York

30. L. H. V. Jimenez, R. H. Hurt, J. Matos, J. R. R. Mendez, Environ. Sci. Technol. 2014, 48, 1166-1174.

DOI:10.1021/es403929b

31. L. Batistella, L. D. Venquiaruto, M. D. Luccio, J. V. Oliveira, S. B. C. Pergher, M. A. Mazutti, D. de Oliveira, A. J Mossi, H. Treichel, R. Dallago, Ind. Eng. Chem. Res. 2011, 50, 68716876. DOI:10.1021/ie101020r

32. J. Sun, S. Zhou, P. Hou, Y. Yang, J. Weng, X. Li, M. Li, J. Biomed. Mater. Res. 2006, 80A, 333-341.

DOI:10.1002/jbm.a.30909

33. S. Shukla, V. Arora, A. Jadaun, J. Kumar, N. Singh, V. K. Jain, Int J. Nanomedicine. J. 2015, 10, 4901-17. DOI:10.2147/IJN.S77675

34. C. Gai, F. Zhang, Q. Lang, T. Liu, N. Peng, Z. Liu, Appl. Catal. B: Environ. 2017, 204, 566-576.

DOI:10.1016/j.apcatb.2016.12.005

35. S. Dwivedi, P. Mondal, C. Balomajumder, Res. J. Chem. Sci. 2014, 4(1), 50-58.

36. T. P. Singh, C. B. Majumder, Int. J. Pharm. Pharm. Sci. 2016, 8, 8-7. DOI:10.22159/ijpps.2016v8i10.12253

37. S. Karthikeyan, R. Balasubramanian, C. S. P. Iyer, Bioresour. Technol. 2007, 98, 452-455. 
DOI:10.1016/j.biortech.2006.01.010

38. M. D. Meitei, M. N. V. Prasad, Ecol. Eng. 2014, 71, 308-317. DOI:10.1016/j.ecoleng.2014.07.036

39. D. Tang, G. Zhang, Chem. Eng. J. 2016, 283, 721-729. DOI:10.1016/j.cej.2015.08.019

40. D. P. Das, J. Das, K. Parida, J. Colloid Interface Sci. 2003, 261, 213-220. DOI:10.1016/S0021-9797(03)00082-1

41. I. J. Langmuir, Am. Chem. Soc. 1916, 38, 2221-2295. DOI:10.1021/ja02268a002

42. H. Freundlich, 1906, 57, 385-470. DOI:10.4236/ojn.2015.56057

43. S. Kundu, A. K. Gupta, Chem. Eng. J. 2006, 122(1-2), 93-106. DOI:10.1016/j.cej.2006.06.002

44. E. Bulut, M. Ozacar, I. A. Sengil, J. Hazard. Mater. 2008, 154, 613-622. DOI:10.1016/j.jhazmat.2007.10.071

45. E. Demirbas, M. Kobya, A. E. S. Konukman, J. Hazard. Mater. 2008, 154, 787-794.

DOI:10.1016/j.jhazmat.2007.10.094

46. Y. S. Ho, G. Mckay, Process Saf. Environ. Prot. 1998, 76, 332340. DOI:10.1205/095758298529696

47. Y. S. Ho, D. A. J. Wase, C. F. Forster, Water Res. 1995, 29, 1327-1332. DOI:10.1016/0043-1354(94)00236-Z

48. F. C. Wu, R. L. Tseng, R. S. Juang, Chem. Eng. J. 2009, 153, 1-8. DOI:10.1016/j.cej.2009.04.042
49. J. W. J. Weber, J. C. Morris, J. Sanit. Eng. Div. ASCE. 1963; 89(SA2), 31-59.

50. J. Singh, K. J. Reddy, Y. Y. Chang, S. H. Kang, J. K. Yang, Process Saf. Environ. Prot. 2016, 99, 88-97.

DOI:10.1016/j.psep.2015.10.011

51. M. E. Mahmoud, G. M. Nabil, N. M. El-Mallah, H. I. Bassiouny, S. Kumar, T. M. Abdel-Fattah, J. Ind. Eng. Chem. 2016, 37, 156-167. DOI:10.1016/j.jiec.2016.03.020

52. Y. Ku, H. Chiou, Water Air Soil Pollut. 2002, 133, 349-361. DOI:10.1023/A:1012929900113

53. H. Huang, J. Liu, P. Zhang, D. Zhang, F. Gao, Chem. Eng. J. 2017, 307, 696-706. DOI:10.1016/j.cej.2016.08.134

54. A. K. Yadav, R. Abbassi, A. Gupta, M. Dadashzadeh, Ecol. Eng. 2013, 52, 211-218. DOI:10.1016/j.ecoleng.2012.12.069

55. H. M Caia, G. J. Chena, C. Y. Penga, Z. Z. Zhanga, Y. Y. Donga, G. Z. Shanga, X. H. Zhua, H. J. Gaob, X. C. Wana, Appl. Surf. Sci. 2015, 328, 34-44.

DOI:134-44. 10.1016/j.apsusc.2014.11.164

56. G. Karthikeyan, S. S. Llango, Iran. J. Environ. Healt. Sci. Eng. 2007, 4, 21-28.

57. S. Sinha, K. P. Pandey, D. Mohan, K. P. Singh, Ind. Eng. Chem. Res. 2003, 42, 6911-6918. DOI:10.1021/ie030544k

58. D. Mohan, R. Sharma, V. K. Singh, P. Steele, C. U. Pittman, Ind. Eng. Chem. Res. 2012, 51, 900-914.

DOI:10.1021/ie202189v

\section{Povzetek}

Tekom študije smo uspešno sintetizirali biogeni aktivni ogljik iz ostankov pulpe limete (Citrus limetta) in ga uporabili za odstranjevanje fluoridnih ionov iz vodne raztopine. Za sintezo aktivnega oglja smo surovino segreli v pečici pri dveh različnih temperaturah $\left(250^{\circ} \mathrm{C}\right.$ in $\left.500^{\circ} \mathrm{C}\right)$ in vzorca označili kot ACP-250 in ACP-500. Pripravljen biosorbent smo karakterizirali z vrstično elektronsko mikroskopijo (SEM), infrardečo spektroskopijo s Fourierjevo transformacijo (FTIR) in rentgensko difrakcijo (XRD). Šaržne študije adsorpcije smo izvedli pri različnih temperaturah, količini, $\mathrm{pH}$ vrednostih in začetnih pogojih. Za razumevanje adsorpcijskega mehanizma smo določili adsorpcijske izoterme in reakcijsko kinetiko. Rezultati študije so pokazali, da je bila maksimalna odstranjena količina ionov znašala za ACP-500 86 \% in za ACP-250 $82 \%$. Izoterme najbolje opišemo $\mathrm{z}$ Langmuirjevo izotermo, $\mathrm{z}$ enoslojno adsorpcijsko kapaciteto fluoridnih ionov 12.6 $\mathrm{mg} / \mathrm{g}$. Vendar pa kinetiko vezave dobro opišemo kot reakcijo psevdo-drugega reda. Sintetizirani material je bil učinkovit za odstranjevanje fluoridinih ionov iz vode pri različnih temperaturah in bil uporaben tri do štirikrat. 